\title{
Critical Success Attributes of Transnational IT Education Programmes: The Client Perspective
}

\author{
Iwona Miliszewska and Ewa M. Sztendur \\ Victoria University, Melbourne, Victoria, Australia
}

Iwona.Miliszewska@vu.edu.au Ewa.Sztendur@vu.edu.au

\section{Executive Summary}

How can transnational education (TNE) programs be made more effective? According to the literature, no one is in a better position to comment on this question than the students themselves. At the same time, there is a recognized scarcity in the literature of student input into the issue of transnational program effectiveness. In consideration of this need, a research study was conducted to examine the effectiveness of TNE programs from the student perspective. To this end, transnational students' views on the various dimensions of the TNE context were used as a key indicator of the effectiveness of transnational programs. The evaluated dimensions included student, instructor, curriculum and instruction design, interaction, evaluation and assessment, technology, and program management, and organisational support. Data for the study was collected from approximately five hundred transnational students participating in eight transnational undergraduate computing programs offered by four Australian universities in Hong Kong, Malaysia, Singapore and Vietnam.

Overall, students from the eight different programs considered in this study were in agreement as to the factors they perceived as most important to the effectiveness of transnational programs. As anticipated and confirmed by the literature, students were of the view that their own motivation, self-discipline, and the ability to work independently, as well as in a team, was a pre-condition of an effective program. With respect to instructors, students attached the greatest importance to the instructors' ability to understand program requirements and student needs, use communication skills effectively, and be well prepared and organized. They were also in agreement regarding the importance of instructors' experience with technology-based programs and their ability to provide well-designed syllabus and presentation outlines. The relevance of the curriculum to job and career was perceived as the most important aspect of program curriculum and instruction design. The alignment of assessment with learning objectives was also considered important, as was assessment of student attitudes and levels of satisfaction. Students identified two aspects of importance in relation to technology: availability and reliability, and the ease of use of technology. With respect to program management and organizational support, timely preparation of program materials was considered important, as was the institution's attention to the high quality of the

Material published as part of this publication, either on-line or in print, is copyrighted by the Informing Science Institute. Permission to make digital or paper copy of part or all of these works for personal or classroom use is granted without fee provided that the copies are not made or distributed for profit or commercial advantage AND that copies 1) bear this notice in full and 2) give the full citation on the first page. It is permissible to abstract these works so long as credit is given. To copy in all other cases or to republish or to post on a server or to redistribute to lists requires specific permission and payment of a fee. Contact Publisher@InformingScience.org to request redistribution permission. program.

The findings of the reported study indicate that to improve and sustain transnational programs in the future, it is essential for universities to gain an understanding of the learners' perspective. The findings provide a framework to assist in making informed decisions in the design, development, and review of transnational programs. 
Keywords: instruction, learning environment, program attributes, program effectiveness, student perspectives, transnational education.

\section{Introduction}

While there may be many definitions of transnational education, the one used in this article describes that type of education, often referred to as offshore education, in which the learners are located in a country different from the one where the awarding institution is based (UNESCO \& the Council of Europe, 2001). This definition includes education that is provided by collaborative arrangements, such as franchising, twinning, joint degrees where study programs are provided by another partner, as well as non-collaborative arrangements such as branch campuses, offshore institutions, and corporate universities. The Australian Department of Education Science and Training (DEST) (2005) provides a definition of Australian Transnational Education; this definition includes two additional requirements:

(1) that the transnational program be delivered and/or assessed by an accredited Australian provider; and

(2) that the delivery includes a face-to-face component.

It further stresses that, in contrast to distance education provided in purely distance mode, transnational education includes a physical presence of instructors offshore either directly by the Australian provider or indirectly through a formal agreement with a local institution.

The demand for transnational higher education in Asian countries (excluding China) is estimated to reach nearly 500,000 students by 2020 (Organisation for Economic Cooperation and Development [OECD], 2009). For Australian universities, who are key transnational providers in the region (Banks, Kevat, Ziguras, Ciccarelli, \& Clayton, 2010; Universities Australia, 2009), ensuring high quality and effectiveness of Australian transnational offerings and satisfying the needs of the highest demand disciplines in the region - computing and business - is of vital importance. Equally important is the need to accommodate the growing interest in the experiences of the participating transnational students. A leading international strategic information provider, The Observatory on Borderless Higher Education (OBHE), identified "student perspectives from those participating in transnational higher education programmes" as a strategic topic for its reports. In consideration of this dual need, the research study reported in this article sought to investigate the issue of transnational program effectiveness from the student perspective. The study aimed to provide feedback (from student perspective) to the question of how transnational education programs could be made more effective. The finding of the study could be pertinent to staff involved in the design, development, and review of transnational programs, as well as to university administrators responsible for making strategic decisions.

\section{Effectiveness of Transnational Programs}

This section focuses on the issue of effectiveness of transnational education programs. The section reviews the definition of effectiveness in transnational context, as well as determinants of program effectiveness.

\section{Definition and Perspectives}

A transnational education program is perceived to be effective if it fulfils the needs of its participants to such an extent that they would be happy to enrol in another similarly designed program. The needs of the learners represent individually and socially defined goals that can be achieved in a variety of ways and relate to a number of learning outcomes. Although the ultimate objective of a program is to enable the learners to achieve their goals, the assessment of its effectiveness in- 
variably involves evaluation of factors at two levels of operation: the individual level and the system level. At the individual level, the learning experience, the practical relevance of acquired skills, and the satisfaction with the learning experience are evaluated. At the system level, the evaluation includes the functional, managerial, and instructional aspects. Whilst student retention and/or repeat enrolments are critical indicators of program effectiveness, Rovai and Downey (2010) have identified planning, marketing and recruitment, financial management, quality assurance, teacher development, and course design and pedagogy as being equally important.

Students perceive a program to be effective if they pass examinations, feel that the content of the program is relevant to their needs, have an opportunity to network with other students, feel part of the class and connected to teachers, have opportunities for participation, receive support when needed, experience few technical problems, and feel comfortable with the technology (Beard \& Harper, 2003; Kenny, 2003; Simonson, Smaldino, Albright, \& Zvacek, 2000). Teachers perceive a program to be effective if students are motivated, complete assessment tasks and participate in discussion, use the technology to communicate, pass examinations, and few students drop out from the program. Teachers also perceive the program to be effective if the program content meets the students' needs and if the institution provides financial, personnel and technical support.

From the perspective of program developers, effective programs are designed to meet diverse needs of students. Students in TNE programs represent a wide variety of backgrounds, experiences, and needs which make it impossible to identify the typical distance student; therefore, an effective program has to cater for varied student profiles. Schonfeld (2005) suggested that standardized program content and student ability to re-visit course material can help overcome this problem. Others have stressed the need to provide for strong personal connections between students and between students and teachers as well as the use of visual media wherever possible, reliable two-way channels of communication, and clearly defined parameters around technical issues and course assessments (Lei \& Gupta, 2010; Reeder, 2010). The effectiveness of a program can be further enhanced if developers understand and apply learning theories to its development and delivery.

From an educational perspective, an effective program should support the universal principles for good practice in education. It should encourage and maximise contacts between students and teachers, develop relationships and promote collaboration among students, incorporate active learning, give rich and rapid feedback to students, stress time-on-task, set high standards for students' performance, and respect individual differences and allow students opportunities for learning that acknowledge those differences (Chickering \& Ehrmann, 1996; Chickering \& Gamson, 1987; McLoughlin, Oliver \& Wood 1999). In other words, it is essential that programs delivered at a distance enable students to 'fit in'.

\section{Determinants}

Phipps \& Merisotis (2000), following a review of program quality measures used by leading distance education institutions, identified seven categories considered essential to ensuring excellence in distance education, especially Internet-based. The categories include: institutional support, course development, teaching/learning, course structure, student support, staff support, and evaluation and assessment. For Kennedy and Duffy (2004, p. 203), "collaboration between...key participants: administrators, teachers, technical support staff, librarians and students" is the key to successful and effective programs.

The amount of interaction/collaboration in a program appears to be an important element of its effectiveness (Kennedy \& Duffy, 2004). Interaction can be defined as "an interplay and exchange in which individuals and groups influence each other" (Rovai \& Barnum, 2003, p. 59). Moore 
(1990) pointed to the content of the interaction between teacher and student and the quality of the communication system facilitating this interaction as determinants of successful distance education. Morgan \& McKenzie (2003) stressed the critical importance of interaction between participants in the distance education environment and regard it as one of the determinants of effectiveness; Palloff \& Pratt (2003) further emphasized the importance of carefully designed and well conducted Web-based interaction. Other studies have focused on specific characteristics in distance education including student satisfaction (M. Allen, Bourhis, Burrell, \& Mabry, 2002); instructional features affecting student achievement (Machtmes \& Asher, 2000); and education technologies in learning (Cavanaugh, 2001; Palloff \& Pratt, 2003). The extent to which online delivery of course content has become a factor in TNE now means that student satisfaction with Web-supported programs is likely to determine whether the student will enrol in future programs in this format or with the same education provider (McGorry, 2003; I. E. Allen \& Seaman, 2004).

Since transnational education is a fusion of education and technology to deliver instructions effectively to students at a distance, the key to an effective distance education program is the effectiveness of the individual components and the flexibility of the interface between them. Some educators argue that the lack of interaction, student-to-student and student-to-teacher, is one of the biggest challenges. Studies show however, that when distance education techniques are used properly, non-traditional interaction can be as effective as the conventional face-to-face interaction (Chernish, DeFranco, Lindner \& Dooley, 2005; Howell \& Jayaratna, 2000).

\section{Research Study: Rationale and Methods}

In view of growing interest in the perceptions of students participating in the transnational programs, a research study was conducted in 2008/2009 to examine the issue of transnational program effectiveness from the 'client' (student) perspective. The study involved students in eight transnational computing programs offered in Hong Kong, Malaysia, Singapore, and Vietnam by Australian universities; four-hundred- and-sixty-nine students participated. Table 1 presents a breakdown of student numbers across providing universities, locales, and programs; it also includes information about the mode of study (part-time, full-time) and the mode of teaching (both Australian and local staff are involved in face-to-face teaching, or local staff only).

Table 1: Number of students participating in the study

\begin{tabular}{|l|l|l|l|l|}
\hline & Hong Kong & Malaysia & Singapore & Vietnam \\
\hline \multirow{3}{*}{ University1 } & $\begin{array}{l}\text { Program1 } \\
\text { (N=131) } \\
\text { part-time }\end{array}$ & $\begin{array}{l}\text { Program2 } \\
\text { (N=44) } \\
\text { full-time }\end{array}$ & & \\
& & $\begin{array}{l}\text { Program3 } \\
\text { (N=69) } \\
\text { full-time }\end{array}$ & $\begin{array}{l}\text { Program4 } \\
\text { (N=46) } \\
\text { part-time }\end{array}$ & $\begin{array}{l}\text { Program5 } \\
\text { (N=33) } \\
\text { full-time }\end{array}$ \\
\hline University2 & & $\begin{array}{l}\text { Program7 } \\
\text { (N=32) } \\
\text { full-time }\end{array}$ & & \\
\hline & $\begin{array}{l}\text { Program6 } \\
\text { (N=44) } \\
\text { part-time }\end{array}$ & & $\begin{array}{l}\text { Program8 } \\
\text { (N=70) } \\
\text { part-time }\end{array}$ & \\
\hline
\end{tabular}

Program delivered by both University and local instructors.

Program delivered by local instructors only.

The choice of locales was deliberate: Hong Kong and Singapore are important markets for Australian transnational programs and are also well-developed territories where English is commonly spoken (Garrett \& Verbik, 2003a, 2003b; IDP Education Australia, 2004); hence, students participating in the study were likely to have the benefit of suitable technological infrastructure and adequate linguistic skills. Malaysia and Vietnam were chosen to check if limited technological 
infrastructure and language proficiency would have a bearing on student perceptions. Similarly, the choice of computing programs was also deliberate: the intention was to seek the views of students who were technology savvy; hence, they were less likely to have negative perceptions of the use of technology in their programs because of techno-phobia alone.

The programs operating in part-time mode involved students who had previous approved tertiary qualifications. Students were normally in full-time employment and usually studied six subjects per year - two subjects per term. The full-time programs typically involved students who were high school leavers. In the programs where teaching was shared by Australian and local academics, lecturers from Australia were responsible for the design of curriculum, detailed teaching plans, continuous and final assessment, as well as face-to-face delivery of twenty five percent of the programs; local lecturers taught the remaining part of the programs. The programs relied on the Internet for communication, e.g., subject Web sites, bulletin boards, and email. Students met with lecturers and fellow students through face-to-face sessions and benefited from Web-based support between sessions. Programs taught exclusively by local staff followed the curriculum detailed by the host university from Australia and accessed online resources provided by the host university; however, Australian lecturers did not participate in face-to-face teaching.

Data was collected through a quantitative survey to measure transnational students' perceptions of the relative importance of various attributes of transnational programs. Literature suggests attributes influencing the effectiveness of these programs, and this provided a basis for the development of the survey instrument (Miliszewska, 2006). Firstly, these attributes were identified (attributes relating to transnational computing programs were of particular interest). Secondly, these attributes were grouped into broader categories - dimensions - describing distinctive aspects of transnational education programs. The dimensions included: Student, Instructors and learning environment, Instructors - Technology and organisation, Curriculum and instruction design, Interaction, Evaluation and assessment, Technology, and Program management and organisational support.

\section{Student Perceptions of Important Program Attributes}

In each dimension, students ranked only the top three attributes that they considered most important to the effectiveness of the program, where $1^{\text {st }}$ indicated most important, $2^{\text {nd }}-$ important, and $3^{\text {rd }}$ - somewhat important; students left the remaining attributes in the dimension without a rank thus considering those not important. The overall importance of an attribute within a dimension was obtained from the sum of the reverse-weighted student preferences for that dimension. The $1^{\text {st }}, 2^{\text {nd }}$, and $3^{\text {rd }}$ preferences were weighted as follows: $1^{\text {st }}$ preference was assigned a weight of 3 , $2^{\text {nd }}$ preference - weight of $2,3^{\text {rd }}$ preference - weight of 1 , and lack of preference - weight of 0 . The overall importance of an attribute within a dimension was obtained from the sum of the reverse-weighted student preferences for that attribute in the dimension. This enabled a simple ranking of attributes, based on a single value, within each dimension.

\section{Student}

Students across all programs were in agreement as to the importance of student motivation and self-discipline to program success; in each of the programs, students regarded this attribute as either most or very important. They also perceived the ability to work independently, as well as part of a team, as highly important (Table 2). 
Table 2: Dimension Student: ranking of attributes

\begin{tabular}{|c|c|c|c|c|c|c|c|c|}
\hline & \multicolumn{4}{|c|}{ University \& local instructors } & \multicolumn{4}{|c|}{ Local instructors only } \\
\hline Attribute & $\begin{array}{c}\text { Prog1 } \\
\text { HK }\end{array}$ & $\begin{array}{l}\text { Prog6 } \\
\text { HK }\end{array}$ & $\begin{array}{l}\text { Prog2 } \\
\text { Mal } \\
\end{array}$ & $\begin{array}{l}\text { Prog8 } \\
\text { Sin }\end{array}$ & $\begin{array}{l}\text { Prog3 } \\
\text { Mal } \\
\end{array}$ & $\begin{array}{l}\text { Prog7 } \\
\text { Mal }\end{array}$ & $\begin{array}{l}\text { Prog4 } \\
\text { Sin }\end{array}$ & $\begin{array}{l}\text { Prog5 } \\
\text { Viet }\end{array}$ \\
\hline Works as a team player. & 109 & 47 & 32 & 35 & 57 & 44 & 64 & 34 \\
\hline $\begin{array}{l}\text { Has positive attitude towards } \\
\text { technology-based learning. }\end{array}$ & 76 & 67 & 19 & 44 & 55 & 22 & 31 & 10 \\
\hline Is motivated and self-disciplined. & 173 & 55 & 60 & 133 & 101 & 36 & 67 & 30 \\
\hline Is confident in using technology. & 78 & 17 & 28 & 21 & 44 & 19 & 18 & 16 \\
\hline Knows how to work independently. & 124 & 30 & 44 & 77 & 58 & 27 & 43 & 37 \\
\hline Is involved and participates. & 89 & 26 & 26 & 27 & 51 & 19 & 20 & 11 \\
\hline $\begin{array}{l}\text { Is willing to ask instructors for as- } \\
\text { sistance. }\end{array}$ & 66 & 22 & 27 & 51 & 30 & 14 & 18 & 24 \\
\hline
\end{tabular}

$\square$ The most important attribute in the dimension.
Second most important attribute in the dimension.
Third most important attribute in the dimension.

\section{Instructors and Learning Environment}

The rankings in the dimension Instructors and learning environment were collected separately for University instructors (only in programs that involved University instructors) and for local instructors (in all programs). With respect to University instructors, students attached the greatest importance to their ability to understand program requirements and students' needs; effective use of communication skills was rated the second most important attribute (Table 3).

Table 3: Dimension University Instructors and learning environment: ranking of attributes

\begin{tabular}{|c|c|c|c|c|}
\hline Attribute & $\begin{array}{c}\text { Prog1 } \\
\text { HK }\end{array}$ & $\begin{array}{c}\text { Prog6 } \\
\text { HK }\end{array}$ & $\begin{array}{c}\text { Prog2 } \\
\text { Mal }\end{array}$ & $\begin{array}{l}\text { Prog8 } \\
\text { Sin }\end{array}$ \\
\hline $\begin{array}{l}\text { Understands program requirements, stu- } \\
\text { dents' characteristics and needs. }\end{array}$ & 141 & 68 & 52 & 95 \\
\hline $\begin{array}{l}\text { Encourages students to take responsibility } \\
\text { for their own learning. }\end{array}$ & 109 & 23 & 18 & 51 \\
\hline $\begin{array}{l}\text { Encourages communication between stu- } \\
\text { dents, and students and instructors. }\end{array}$ & 128 & 37 & 37 & 43 \\
\hline $\begin{array}{l}\text { Demonstrates dedication to program, teach- } \\
\text { ing and students. }\end{array}$ & 97 & 51 & 40 & 74 \\
\hline Uses effective communication skills. & 142 & 54 & 64 & 60 \\
\hline $\begin{array}{l}\text { Conducts students' needs assessment and } \\
\text { program evaluation. }\end{array}$ & 59 & 12 & 11 & 25 \\
\hline Ensures students' support services. & 48 & 20 & 12 & 27 \\
\hline
\end{tabular}

\footnotetext{
The most important attribute in the dimension.
Second most important attribute in the dimension.
Third most important attribute in the dimension.
} 
With respect to local instructors (in all programs taught by University and local instructors, as well as those taught by local instructors only), students in all programs agreed that the instructors' understanding of program requirements and students' needs was of utmost importance, as illustrated in Table 4. The same attribute was considered as most important also with respect to University instructors.

Table 4: Dimension Local Instructors and learning environment: ranking of attributes

\begin{tabular}{|l|c|c|c|c||c|c|c|c|}
\cline { 2 - 10 } \multicolumn{1}{c|}{} & \multicolumn{3}{c|}{ University \& local instructors } & \multicolumn{3}{c|}{ Local instructors only } \\
\hline & $\begin{array}{c}\text { Prog1 } \\
\text { HK }\end{array}$ & $\begin{array}{c}\text { Prog6 } \\
\text { HK }\end{array}$ & $\begin{array}{l}\text { Prog2 } \\
\text { Mal }\end{array}$ & $\begin{array}{l}\text { Prog8 } \\
\text { Sin }\end{array}$ & $\begin{array}{l}\text { Prog3 } \\
\text { Mal }\end{array}$ & $\begin{array}{l}\text { Prog7 } \\
\text { Mal }\end{array}$ & $\begin{array}{l}\text { Prog4 } \\
\text { Sin }\end{array}$ & $\begin{array}{l}\text { Prog5 } \\
\text { Viet }\end{array}$ \\
\hline \hline $\begin{array}{l}\text { Understands program reqs, stu- } \\
\text { dents' characteristics and needs. }\end{array}$ & 166 & 86 & 46 & 92 & 105 & 44 & 62 & 38 \\
\hline $\begin{array}{l}\text { Encourages students to take re- } \\
\text { sponsibility for their own learning. }\end{array}$ & 95 & 14 & 23 & 44 & 45 & 19 & 39 & 30 \\
\hline $\begin{array}{l}\text { Encourages communication be- } \\
\text { tween sts, and sts and instructors. }\end{array}$ & 119 & 36 & 36 & 52 & 65 & 40 & 41 & 28 \\
\hline $\begin{array}{l}\text { Demonstrates dedication to pro- } \\
\text { gram, teaching and students. }\end{array}$ & 84 & 29 & 37 & 71 & 56 & 13 & 47 & 25 \\
\hline $\begin{array}{l}\text { Uses effective communication } \\
\text { skills. }\end{array}$ & 138 & 51 & 61 & 53 & 92 & 38 & 36 & 20 \\
\hline $\begin{array}{l}\text { Conducts students' needs as- } \\
\text { sessment and program evaluation. }\end{array}$ & 61 & 8 & 20 & 26 & 25 & 9 & 22 & 11 \\
\hline $\begin{array}{l}\text { Ensures students' support ser- } \\
\text { vices. }\end{array}$ & 58 & 38 & 14 & 26 & 8 & 17 & 11 & 10 \\
\hline
\end{tabular}

The most important attribute in the dimension.

Second most important attribute in the dimension.

Third most important attribute in the dimension.

\section{Instructors - Technology and Organisation}

The rankings in the dimension Instructors - technology and organisation were collected separately for University instructors (only in programs that involved University instructors) and for local instructors (in all programs). Students across all evaluated programs unanimously declared University instructors' preparedness for classes and their good organisation as the most important attribute. They were also in agreement regarding the next two most important characteristics, nominating instructors' experience with technology-based programs and the ability to provide well-designed syllabus and presentation outlines. Students were in similar agreement in terms of the least important instructor attribute in this dimension rating the instructor's ability to develop effective graphics as barely important (Table 5). 
Table 5: Dimension University Instructors - technology and organisation: ranking of attributes

\begin{tabular}{|l|c|c|c|c|}
\hline \multicolumn{1}{|c|}{ Attribute } & $\begin{array}{c}\text { Prog1 } \\
\text { HK }\end{array}$ & $\begin{array}{c}\text { Prog6 } \\
\text { HK }\end{array}$ & $\begin{array}{c}\text { Prog2 } \\
\text { Mal }\end{array}$ & $\begin{array}{c}\text { Prog8 } \\
\text { Sin }\end{array}$ \\
\hline \hline Has positive attitude towards technology. & 50 & 18 & 23 & 39 \\
\hline Demonstrates control over technology. & 46 & 6 & 12 & 29 \\
\hline $\begin{array}{l}\text { Adapts program materials for delivery } \\
\text { through electronic media. }\end{array}$ & 57 & 19 & 11 & 23 \\
\hline $\begin{array}{l}\text { Has experience with technology-based pro- } \\
\text { grams. }\end{array}$ & 80 & 51 & 50 & 55 \\
\hline Is well prepared and organised. & 212 & 73 & 73 & 96 \\
\hline Is proficient in instructional design. & 48 & 24 & 17 & 41 \\
\hline Uses interactive instructional strategies. & 79 & 29 & 22 & 24 \\
\hline $\begin{array}{l}\text { Provides well-designed syllabus and pres- } \\
\text { entation outlines. }\end{array}$ & 118 & 45 & 25 & 52 \\
\hline Develops effective graphics. & 21 & 0 & 2 & 7 \\
\hline
\end{tabular}

\footnotetext{
The most important attribute in the dimension.
Second most important attribute in the dimension.
Third most important attribute in the dimension.
}

With respect to local instructors, students in all programs considered unanimously that first and foremost the instructors should be well prepared and organised; students selected the same attribute as most important with respect to University instructors. Experience with technology-based programs was rated second in terms of importance by the majority of participants (a similar ranking as for University instructors). In terms of the least important attribute, students again were in agreement ranking the local instructor's ability to develop effective graphics lowest; this was the same lowest ranking attribute as the one related to University instructors (Table 6). 
Table 6: Dimension Local Instructors - technology and organisation: ranking of attributes

\begin{tabular}{|l|c|c|c|c||c|c|c|c|}
\cline { 2 - 9 } \multicolumn{1}{c|}{} & \multicolumn{2}{c|}{ University \& local instructors } & \multicolumn{3}{c|}{ Local instructors only } \\
\hline \multicolumn{1}{c|}{ Attribute } & $\begin{array}{l}\text { Prog1 } \\
\text { HK }\end{array}$ & $\begin{array}{l}\text { Prog6 } \\
\text { HK }\end{array}$ & $\begin{array}{l}\text { Prog2 } \\
\text { Mal }\end{array}$ & $\begin{array}{l}\text { Prog8 } \\
\text { Sin }\end{array}$ & $\begin{array}{l}\text { Prog3 } \\
\text { Mal }\end{array}$ & $\begin{array}{l}\text { Prog7 } \\
\text { Mal }\end{array}$ & $\begin{array}{l}\text { Prog4 } \\
\text { Sin }\end{array}$ & $\begin{array}{l}\text { Prog5 } \\
\text { Viet }\end{array}$ \\
\hline \hline $\begin{array}{l}\text { Has positive attitude towards } \\
\text { technology. }\end{array}$ & 63 & 18 & 23 & 35 & 55 & 21 & 36 & 26 \\
\hline $\begin{array}{l}\text { Demonstrates control over tech- } \\
\text { nology. }\end{array}$ & 51 & 26 & 14 & 36 & 16 & 9 & 35 & 11 \\
\hline $\begin{array}{l}\text { Adapts program materials for de- } \\
\text { livery through electronic media. }\end{array}$ & 55 & 13 & 18 & 19 & 41 & 13 & 33 & 15 \\
\hline $\begin{array}{l}\text { Has experience with technology- } \\
\text { based programs. }\end{array}$ & 90 & 41 & 50 & 41 & 69 & 22 & 40 & 31 \\
\hline Is well prepared and organised. & 200 & 84 & 70 & 110 & 119 & 68 & 51 & 33 \\
\hline Is proficient in instructional design. & 46 & 22 & 20 & 30 & 12 & 4 & 18 & 8 \\
\hline $\begin{array}{l}\text { Uses interactive instructional } \\
\text { strategies. }\end{array}$ & 81 & 35 & 18 & 31 & 31 & 17 & 25 & 14 \\
\hline $\begin{array}{l}\text { Provides well-designed syllabus } \\
\text { and presentation outlines. }\end{array}$ & 102 & 26 & 14 & 45 & 44 & 25 & 18 & 10 \\
\hline Develops effective graphics. & 16 & 1 & 8 & 16 & 9 & 0 & 3 & 1 \\
\hline
\end{tabular}

The most important attribute in the dimension.

Second most important attribute in the dimension.

Third most important attribute in the dimension.

\section{Curriculum and Instruction Design}

With respect to curriculum and instruction design, its relevance to job/career was considered the most important attribute by students in all but one of the participating programs, as illustrated in Table 7; only students in Prog8 rated it as the second most important attribute.

Table 7: Dimension Curriculum and instruction design: ranking of attributes

\begin{tabular}{|l|r|r|r|r||r|r|r|r|}
\cline { 2 - 10 } \multicolumn{1}{c|}{ Attribute } & \multicolumn{2}{c|}{ University \& local instructors } & \multicolumn{3}{c|}{ Local instructors only } \\
\hline \multicolumn{1}{c|}{$\begin{array}{l}\text { Prog1 } \\
\text { RK }\end{array}$} & $\begin{array}{l}\text { Prog6 } \\
\text { Mrog2 }\end{array}$ & $\begin{array}{l}\text { Prog8 } \\
\text { Sin }\end{array}$ & $\begin{array}{l}\text { Prog3 } \\
\text { Mal }\end{array}$ & $\begin{array}{l}\text { Prog7 } \\
\text { Mal }\end{array}$ & $\begin{array}{l}\text { Prog4 } \\
\text { Sin }\end{array}$ & $\begin{array}{l}\text { Prog5 } \\
\text { Viet }\end{array}$ \\
\hline \hline $\begin{array}{l}\text { Relates the new material to previ- } \\
\text { ous student knowledge. }\end{array}$ & 104 & 42 & 28 & 52 & 56 & 38 & 26 & 10 \\
\hline $\begin{array}{l}\text { Integrates all program elements } \\
\text { into a well-paced package. }\end{array}$ & 105 & 41 & 35 & 72 & 53 & 27 & 32 & 23 \\
\hline Is relevant to job/career. & 156 & 62 & 62 & 69 & 105 & 39 & 68 & 39 \\
\hline $\begin{array}{l}\text { Creates logical sequences for } \\
\text { each element presented. }\end{array}$ & 91 & 27 & 28 & 56 & 57 & 24 & 46 & 16 \\
\hline $\begin{array}{l}\text { Communicates program objectives } \\
\text { and learning outcomes. }\end{array}$ & 125 & 43 & 26 & 53 & 42 & 22 & 39 & 26 \\
\hline $\begin{array}{l}\text { Instructors and students agree on } \\
\text { deadlines for completion and } \\
\text { marking of assignments. }\end{array}$ & 65 & 17 & 34 & 42 & 50 & 21 & 24 & 20 \\
\hline $\begin{array}{l}\text { Learning objectives are supported } \\
\text { by instructional methodologies. }\end{array}$ & 54 & 31 & 21 & 27 & 33 & 8 & 18 & 16 \\
\hline
\end{tabular}

The most important attribute in the dimension.

Second most important attribute in the dimension.

Third most important attribute in the dimension. 


\section{Interaction}

Timely feedback on assignments and projects was rated as the most important attribute by most students. Interestingly, students expressed low levels of satisfaction with this very aspect of their current programs (Table 8). Second in overall importance were strategies encouraging communication between students, as well as between students and instructors.

Table 8: Dimension Interaction: ranking of attributes

\begin{tabular}{|l|r|r|r|r||r|r|r|r|}
\multicolumn{1}{c|}{ Attribute } & \multicolumn{3}{c|}{ University \& local instructors } & \multicolumn{4}{c|}{ Local instructors only } \\
\hline & $\begin{array}{l}\text { Prog1 } \\
\text { HK }\end{array}$ & $\begin{array}{l}\text { Prog6 } \\
\text { HK }\end{array}$ & $\begin{array}{l}\text { Prog2 } \\
\text { Mal }\end{array}$ & $\begin{array}{l}\text { Prog8 } \\
\text { Sin }\end{array}$ & $\begin{array}{l}\text { Prog3 } \\
\text { Mal }\end{array}$ & $\begin{array}{l}\text { Prog7 } \\
\text { Mal }\end{array}$ & $\begin{array}{l}\text { Prog4 } \\
\text { Sin }\end{array}$ & $\begin{array}{l}\text { Prog5 } \\
\text { Viet }\end{array}$ \\
\hline \hline $\begin{array}{l}\text { Timely feedback on assignments } \\
\text { and projects. }\end{array}$ & 145 & 90 & 62 & 89 & 77 & 61 & 61 & 25 \\
\hline $\begin{array}{l}\text { Involvement in small learning } \\
\text { groups. }\end{array}$ & 118 & 21 & 23 & 53 & 63 & 21 & 40 & 36 \\
\hline Interactive instructional strategies. & 117 & 59 & 30 & 54 & 68 & 33 & 45 & 16 \\
\hline $\begin{array}{l}\text { Frequent contact with the instruc- } \\
\text { tor. }\end{array}$ & 101 & 34 & 35 & 52 & 76 & 25 & 37 & 21 \\
\hline $\begin{array}{l}\text { Interaction with instructors through } \\
\text { electronic media and telephone. }\end{array}$ & 98 & 25 & 18 & 63 & 28 & 10 & 32 & 20 \\
\hline $\begin{array}{l}\text { Strategies encouraging communi- } \\
\text { cation btw sts, \& sts \& instructors. }\end{array}$ & 122 & 35 & 67 & 61 & 83 & 29 & 43 & 33 \\
\hline
\end{tabular}

\footnotetext{
The most important attribute in the dimension.
Second most important attribute in the dimension.
Third most important attribute in the dimension.
}

\section{Evaluation and Assessment}

Students rated highest the assessment of the practical relevance of the program; this corresponds to the high importance rating that the students gave to the relevance of the curriculum and instruction design to job/career (Table 9). The alignment of assessment with learning objectives was also considered important, as was assessment of student attitudes and levels of satisfaction.

Table 9: Dimension Evaluation and assessment: ranking of attributes

\begin{tabular}{|c|c|c|c|c|c|c|c|c|}
\hline & \multicolumn{4}{|c|}{ University \& local instructors } & \multicolumn{4}{|c|}{ Local instructors only } \\
\hline Attribute & $\begin{array}{l}\text { Prog1 } \\
\text { HK }\end{array}$ & $\begin{array}{l}\text { Prog6 } \\
\text { HK }\end{array}$ & $\begin{array}{l}\text { Prog2 } \\
\text { Mal }\end{array}$ & $\begin{array}{l}\text { Prog8 } \\
\text { Sin }\end{array}$ & $\begin{array}{l}\text { Prog3 } \\
\text { Mal }\end{array}$ & $\begin{array}{l}\text { Prog7 } \\
\text { Mal }\end{array}$ & $\begin{array}{l}\text { Prog4 } \\
\text { Sin }\end{array}$ & $\begin{array}{l}\text { Prog5 } \\
\text { Viet }\end{array}$ \\
\hline $\begin{array}{l}\text { Assessment of students' attitudes } \\
\text { and levels of satisfaction. }\end{array}$ & 137 & 61 & 48 & 67 & 96 & 29 & 49 & 26 \\
\hline $\begin{array}{l}\text { Assessment of the relevance of } \\
\text { program content in practice. }\end{array}$ & 167 & 59 & 59 & 109 & 81 & 52 & 64 & 43 \\
\hline $\begin{array}{l}\text { Methods of assessment match } \\
\text { learning objectives. }\end{array}$ & 163 & 58 & 60 & 82 & 97 & 51 & 65 & 34 \\
\hline $\begin{array}{l}\text { Continuous evaluation of students' } \\
\text { academic progress. }\end{array}$ & 133 & 53 & 31 & 66 & 71 & 24 & 38 & 22 \\
\hline $\begin{array}{l}\text { Continuous evaluation of the pro- } \\
\text { gram. }\end{array}$ & 77 & 33 & 36 & 47 & 51 & 26 & 36 & 25 \\
\hline
\end{tabular}

The most important attribute in the dimension.

Second most important attribute in the dimension.

Third most important attribute in the dimension. 


\section{Technology}

Availability and reliability of technology was rated as the most important attribute in this dimension by the majority of students. It is worth noting that students in Prog6, Prog2, and Prog3, who rated this attribute as the most important, were also least satisfied with the quality of technical support provided in their current programs (Table 10). Students also rated as important the ease of use of technology.

Table 10: Dimension Technology: ranking of attributes

\begin{tabular}{|c|c|c|c|c|c|c|c|c|}
\hline & \multicolumn{4}{|c|}{ University \& local instructors } & \multicolumn{4}{|c|}{ Local instructors only } \\
\hline Attribute & $\begin{array}{l}\text { Prog1 } \\
\text { HK }\end{array}$ & $\begin{array}{l}\text { Prog6 } \\
\text { HK }\end{array}$ & $\begin{array}{l}\text { Prog2 } \\
\text { Mal }\end{array}$ & $\begin{array}{l}\text { Prog8 } \\
\text { Sin }\end{array}$ & $\begin{array}{l}\text { Prog3 } \\
\text { Mal }\end{array}$ & $\begin{array}{l}\text { Prog7 } \\
\text { Mal }\end{array}$ & $\begin{array}{l}\text { Prog4 } \\
\text { Sin }\end{array}$ & $\begin{array}{l}\text { Prog5 } \\
\text { Viet }\end{array}$ \\
\hline Current products are used. & 101 & 67 & 44 & 71 & 68 & 33 & 58 & 25 \\
\hline Helpful and easy to use. & 194 & 60 & 53 & 91 & 91 & 59 & 63 & 26 \\
\hline Available and reliable. & 183 & 69 & 71 & 89 & 111 & 45 & 69 & 43 \\
\hline $\begin{array}{l}\text { Software applications are appro- } \\
\text { priate and easy to use. }\end{array}$ & 147 & 35 & 43 & 79 & 76 & 19 & 45 & 33 \\
\hline $\begin{array}{l}\text { Access to technical assistance } \\
\text { throughout the program. }\end{array}$ & 64 & 27 & 24 & 44 & 44 & 19 & 23 & 24 \\
\hline
\end{tabular}

The most important attribute in the dimension.

Second most important attribute in the dimension.

Third most important attribute in the dimension.

\section{Program Management and Organisational Support}

With respect to program management and organisational support, timely preparation of program materials was considered important, as was the institution's attention to the high quality of the program (Table 11).

Table 11: Dimension Program management and organisational support: ranking of attributes

\begin{tabular}{|l|c|c|c|c||c|c|c|c|}
\cline { 2 - 9 } \multicolumn{1}{c|}{} & \multicolumn{3}{c||}{ University \& local instructors } & \multicolumn{3}{c|}{ Local instructors only } \\
\hline \multicolumn{1}{|c|}{ Attribute } & $\begin{array}{c}\text { Prog1 } \\
\text { HK }\end{array}$ & $\begin{array}{l}\text { Prog6 } \\
\text { HK }\end{array}$ & $\begin{array}{l}\text { Prog2 } \\
\text { Mal }\end{array}$ & $\begin{array}{l}\text { Prog8 } \\
\text { Sin }\end{array}$ & $\begin{array}{l}\text { Prog3 } \\
\text { Mal }\end{array}$ & $\begin{array}{l}\text { Prog7 } \\
\text { Mal }\end{array}$ & $\begin{array}{l}\text { Prog4 } \\
\text { Sin }\end{array}$ & $\begin{array}{l}\text { Prog5 } \\
\text { Viet }\end{array}$ \\
\hline \hline $\begin{array}{l}\text { Timely preparation of program } \\
\text { materials. }\end{array}$ & 129 & 64 & 51 & 76 & 79 & 53 & 50 & 13 \\
\hline $\begin{array}{l}\text { Procedures exist to quickly re- } \\
\text { spond to student complaints. }\end{array}$ & 132 & 36 & 27 & 46 & 66 & 24 & 42 & 27 \\
\hline $\begin{array}{l}\text { Institution ensures high quality of } \\
\text { the program. }\end{array}$ & 139 & 50 & 44 & 90 & 76 & 27 & 62 & 28 \\
\hline $\begin{array}{l}\text { Student support services are pro- } \\
\text { vided (e.g. student registration, } \\
\text { ordering of textbooks) }\end{array}$ & 151 & 55 & 43 & 62 & 76 & 23 & 49 & 32 \\
\hline $\begin{array}{l}\text { Training is provided on accessing } \\
\text { program Web sites, electronic } \\
\text { databases, etc. }\end{array}$ & 80 & 25 & 18 & 51 & 40 & 13 & 35 & 31 \\
\hline $\begin{array}{l}\text { Effective overall program coordi- } \\
\text { nation. }\end{array}$ & 65 & 31 & 50 & 41 & 55 & 32 & 23 & 19 \\
\hline
\end{tabular}

The most important attribute in the dimension.

Second most important attribute in the dimension.

Third most important attribute in the dimension. 


\section{Summary of Critical Program Success Attributes}

There was a great degree of agreement on the critical attributes between the students in the eight evaluated programs. In each of the programs, three attributes ranked highest in each dimension were used for comparative analysis between the programs. Table 12 presents a summary of this analysis. In each dimension, only attributes ranked among the highest three in at least six out of eight programs are listed. Since University instructors were involved only in four of the evaluated programs, in dimensions related to University instructors only attributes ranked among the highest three in at least three out of four programs are listed.

Table 12: Student perceptions of critical success attributes

\begin{tabular}{|c|c|c|}
\hline Dimension & Attribute & Program \\
\hline \multirow{3}{*}{ Student } & Is motivated and self-disciplined. & $1,2,3,4,5,6,7,8$ \\
\hline & Knows how to work independently. & $1,2,3,4,5,7,8$ \\
\hline & Works as a team player. & $1,2,3,4,5,6,7$ \\
\hline \multirow{3}{*}{$\begin{array}{l}\text { University instruc- } \\
\text { tor and learning } \\
\text { environment }\end{array}$} & $\begin{array}{l}\text { Understands program requirements, students' characteristics and } \\
\text { needs. }\end{array}$ & $1,2,6,8$ \\
\hline & Uses effective communication skills. & $1,2,6,8$ \\
\hline & Demonstrates dedication to program, teaching and students. & $2,6,8$ \\
\hline \multirow{2}{*}{$\begin{array}{l}\text { Local instructor } \\
\text { and learning envi- } \\
\text { ronment }\end{array}$} & $\begin{array}{l}\text { Understands program requirements, students' characteristics and } \\
\text { needs. }\end{array}$ & $1,2,3,4,5,6,7,8$ \\
\hline & Uses effective communication skills. & $1,2,3,6,7,8$ \\
\hline \multirow{3}{*}{$\begin{array}{l}\text { University instruc- } \\
\text { tor - Technology } \\
\text { and organisation }\end{array}$} & Is well prepared and organised. & $1,2,6,8$ \\
\hline & Has experience with technology-based programs. & $1,2,6,8$ \\
\hline & Provides well-designed syllabus and presentation outlines. & $1,2,6,8$ \\
\hline \multirow{2}{*}{$\begin{array}{l}\text { Local instructor - } \\
\text { Technology and } \\
\text { organisation }\end{array}$} & Is well prepared and organised. & $1,2,3,4,5,6,7,8$ \\
\hline & Has experience with technology-based programs. & $1,2,3,4,5,6,7,8$ \\
\hline $\begin{array}{l}\text { Curriculum and } \\
\text { instruction design }\end{array}$ & Is relevant to job/career. & $1,2,3,4,5,6,7,8$ \\
\hline \multirow[b]{2}{*}{ Interaction } & Timely feedback on assignments and projects. & $1,2,3,4,5,6,7,8$ \\
\hline & $\begin{array}{l}\text { Strategies that encourage communication between students, and stu- } \\
\text { dents and instructors. }\end{array}$ & $1,2,3,4,5,6,7,8$ \\
\hline \multirow{3}{*}{$\begin{array}{l}\text { Evaluation and } \\
\text { assessment }\end{array}$} & Assessment of the relevance of course content in practice. & $1,2,3,4,5,6,7,8$ \\
\hline & Methods of assessment match learning objectives. & $1,2,3,4,5,6,7,8$ \\
\hline & Assessment of students' attitudes and levels of satisfaction. & $1,2,3,4,5,6,7,8$ \\
\hline \multirow{2}{*}{ Technology } & Is available and reliable. & $1,2,3,4,5,6,7,8$ \\
\hline & Is helpful and easy to use. & $1,2,3,4,5,6,7,8$ \\
\hline \multirow{3}{*}{$\begin{array}{l}\text { Course manage- } \\
\text { ment and organ- } \\
\text { isational support }\end{array}$} & Timely preparation of course materials. & $2,3,4,6,7,8$ \\
\hline & Institution ensures high quality of the course. & $1,2,3,4,5,6,7,8$ \\
\hline & Student support services are provided. & $1,3,4,5,6,8$ \\
\hline
\end{tabular}

The most important attribute in the dimension. 
Transnational students, irrespective of the origin and type of the program (its offering institution, offshore locale, study mode, teaching mode), were in agreement as to the factors they considered most important to the effectiveness of transnational programs; the extent of agreement was substantial. Students identified the following critical success attributes: (1) the ability of instructors (both, University as well as local) to understand program requirements, student characteristics and needs, as well as their preparedness for classes; (2) the relevance of the program content to job/career; (3) timely provision of course materials and feedback on assessment tasks; and, (4) availability and reliability of technology.

\section{Conclusion}

Student perspectives outlined in this article were collected with the notion in mind that, as the ultimate clients of an education program, students should participate in defining what constitutes its effectiveness. The article offers an insight into learners' perceptions of their educational beliefs by providing a detailed account of the wide range of factors that might have influence on those perceptions.

Research on the effectiveness of transnational education faces the dilemma that the educational context is not homogenous, as it involves different types of educational providers, students, and partner institutions across many countries, and it includes a variety of program delivery models. In addition, the educational context is constantly evolving due to the introduction of new technologies and, resulting from it, the introduction of new ways of teaching and learning.

The findings reported in this article show that transnational students from eight different undergraduate computing programs in South East Asia are in agreement as to the factors they consider most important to the effectiveness of transnational programs. The findings also seem to support the premise that technology represents but one dimension of the transnational education context, and that other dimensions also contribute to program effectiveness. This article provides support for investigating effectiveness of transnational programs in that, irrespective of how the educational context may change in the future, the fundamental factors that impact learning and success have been identified by 'clients': the transnational students themselves.

Given the information contained in this article, it is evident that to improve and sustain transnational programs in the future, it is essential for universities to gain an understanding of the learners' perspective: an understanding that transcends attendance records and academic achievements. The findings reported in this article provide a framework to assist in making informed decisions in the design, development, and review of transnational programs.

\section{References}

Allen, I. E., \& Seaman, J. (2004). Entering the mainstream: The quality and extent of online education in the United States, 2003 and 2004. Retrieved October 15, 2010, from http://www.sloanconsortium.org/publications/survey/entering the mainstream2004

Allen, M., Bourhis, J., Burrell, N., \& Mabry, E. (2002). Comparing student satisfaction with distance education to traditional classrooms in higher education: A meta-analysis. The American Journal of Distance Education, 16, 83-97.

Banks, M., Kevat, P., Ziguras, C., Ciccarelli, A. \& Clayton, D. (2010). The changing fortunes of Australian transnational higher education. London: Observatory on Borderless Higher Education. Available at http://www.obhe.ac.uk/documents/view_details?id=835

Beard, L. A., \& Harper, C. (2002). Student perceptions of online versus on campus instruction. Education, 122 (4), 658-663. Retrieved November 10, 2010, from http://findarticles.com/p/articles/mi_qa3673/is_4_122/ 
Cavanaugh, C. S. (2001). The effectiveness of interactive distance education technologies in K-12 learning: A meta-analysis. International Journal of Educational Telecommunications, 7(1), 73-88.

Chernish, W. N., DeFranco, A. L, Lindner, J. R., \& Dooley, K. E. (2005). Does it matter? Analyzing the results of three different learning delivery methods. The Quarterly Review of Distance Education, 6 (2), 87-95.

Chickering, A. W., \& Ehrmann, S. C. (1996). Implementing the seven principles: Technology as lever. AAHE Bulletin, 49(2), 3-6. Retrieved March 12, 2010, from http://www.tltgroup.org/programs/seven.html

Chickering, A. W., \& Gamson, Z. (1987). Seven principles of good practice in undergraduate education. AAHE Bulletin, 39(7), 3-6.

Department of Education, Science and Training (DEST). (2005). A national quality strategy for Australian transnational education and training: A discussion paper. Retrieved March 10, 2011, from http://www.aei.gov.au/AEI/GovernmentActivities/QAAustralianEducationAndTrainingSystem/QualSt rat pdf.pdf

Garrett, R., \& Verbik, L. (2003a). Transnational higher education, part 1: The major markets - Hong Kong and Singapore. The Observatory, 14, November.

Garrett, R., \& Verbik, L. (2003b). Transnational higher education, part 1: Shifting markets and emerging trends. The Observatory, 15, December.

Howell, B., \& Jayaratna, N. (2000). Demonstration of how soft systems methodology can be used to structure the issues associated with distance learning activities. In G. Orange \& D. Hobbs (Eds.), International perspectives on tele-education and virtual learning environments (pp. 91-108). Aldershot, England: Ashgate Publishing.

IDP Education Australia. (2004). International students in Australian universities. Report. Canberra, IDP. Retrieved August 5, 2010, from http://www.idp.com/research/fastfacts/Semester\%20Two\%202004\%20\%20Key\%20Outcomes Web.pdf

Kennedy, D., \& Duffy, T. (2004). Collaboration - a key principle in distance education. Open Learning, 19(2), 203-211.

Kenny, J. (2003). Student perception of the use of online learning technology in their courses. Retrieved November 2, 2010, from http://ultibase.rmit.edu.au/Articles/march03/kenny2.htm

Lei, S. A., \& Gupta, R. K. (2010). College distance education courses: Evaluating benefits and costs from institutional, faculty and students' perspectives. Education, 130(4), 616-631.

Machtmes, K., \& Asher, J. W. (2000). A meta-analysis of the effectiveness of telecourses in distance education. American Journal of Distance Education, 14(1), 27-46.

McGorry, S. M. (2003). Measuring quality in online programs. Internet and Higher Education, 6(2), 159177.

McLoughlin, C., Oliver, R., \& Wood, D. (1999). Pedagogic roles and dynamics in telematics environments. In M. Selinger, \& J. Pearson (Eds.), Telematics in education: Trends and issues (pp. 32-50). Oxford, U.K.: Elsevier Science Ltd.

Miliszewska, I. (2006). A multidimensional model for transnational computing education programs. $\mathrm{PhD}$ thesis, Victoria University.

Moore, M. G. (1990). Recent contribution to the theory of distance education. Open Learning, 5(3), 10-15.

Moore, M. G., \& Kearsley, G. (2005). Distance education: A systems view (2nd ed.). Toronto, Wadsworth.

Morgan, C. K., \& McKenzie, A. D. (2003). Is enough too much? The dilemma for online distance learner supporters. International Review of Research in Open and Distance Learning, 4(1). Retrieved November 2, 2010, from http://www.irrodl.org/content/v4.1/mckenzie_morgan.html 
Organisation for Economic Cooperation and Development (OECD). (2009). Higher education to 2030: Globalisation. London: OECD Publishing.

Palloff, R. M., \& Pratt, K. (2003). The virtual student. A profile and guide to working with online learners. San Francisco: Jossey Bass

Phipps, R., \& Merisotis, J. (2000). Quality on the line: Benchmarks for success in internet-based distance education. Washington, DC: Institute for Higher Education Policy. Retrieved March 5, 2010, from http://www.ihep.com/quality.pdf

Reeder, C. (2010). Keys to creating a successful online course for do-it-yourselfers. Education Digest, 75(5), 24-27.

Rovai, A. P., \& Barnum, K. T. (2003). On-line course effectiveness: An analysis of student interactions and perceptions of learning. Journal of Distance Education, 18(1), 57-73.

Rovai, A. P., \& Downey, J. R. (2010). Why some distance education programs fail while others succeed in a global environment. Internet and Higher Education, 13(3), 141-147.

Schonfeld, T. L. (2005). Reflections on teaching health care ethics on the web. Science and Engineering Ethics, 11(3), 481-494.

Simonson, M., Smaldino, S., Albright, M., \& Zvacek, S. (2000). Teaching and learning at a distance: Foundations of distance education. Upper Saddle River, New York: Prentice Hall.

UNESCO \& Council of Europe. (2001). Code of good practice in the provision of transnational education. UNESCO-CEPES, Bucharest. Retrieved March 15, 2011, from http://www.cepes.ro/hed/recogn/groups/transnat/code.htm

Universities Australia. (2009). Offshore Programs of Australian Universities. Canberra, AVCC.

\section{Biographies}

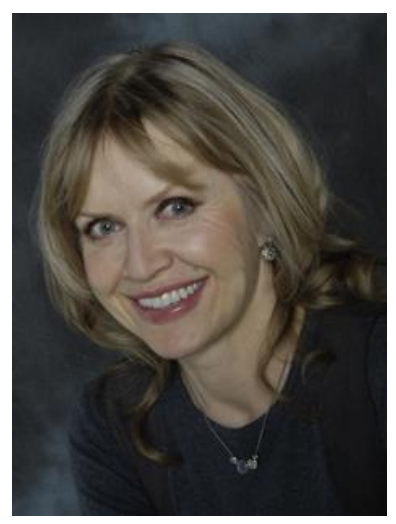

Dr Iwona Miliszewska is Associate Professor in computer science at Victoria University in Melbourne, Australia. She has led and participated in research projects involving transnational education, effective teaching methods, technology-supported learning, and females in ICT, and has published in these areas.

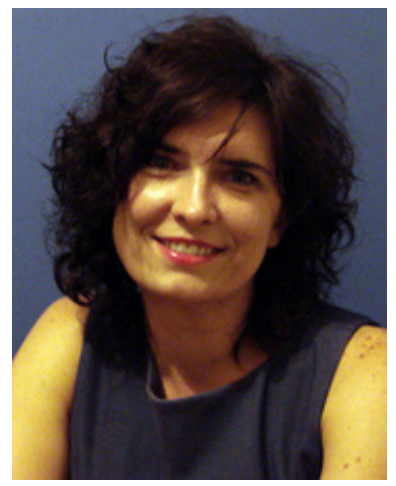

Dr Ewa Sztendur is a Research Fellow in the Office of the Pro ViceChancellor (Students and Learning and Teaching) at Victoria University in Melbourne, Australia. She has a PhD in statistics (experimental design) and has been involved in numerous research projects related to the issues of higher education, including widening participation, gender equity, student use of technology, and student retention and performance. 